
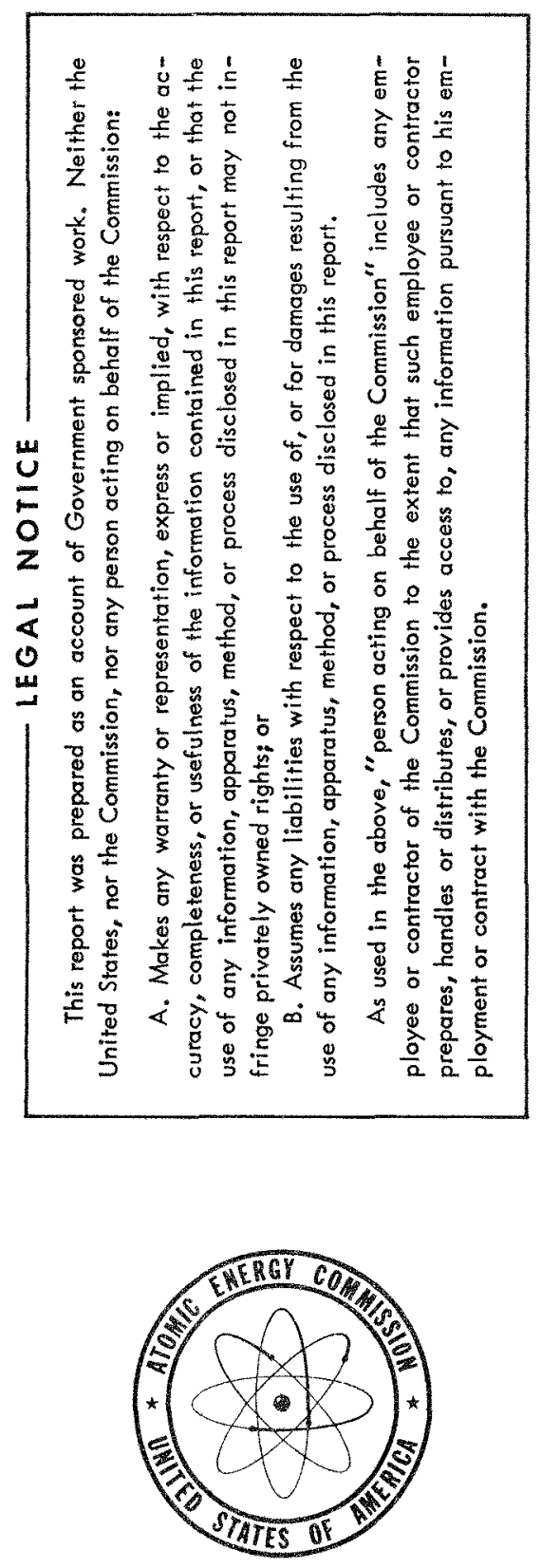

UNITED STATES ATOMIC ENERGY COMMISSION

HYDROFLUORINATION OF ZIRCONIUM OXIDE

By

Don Phillips

Photostat Price $\$$
Microfilm Price $\$$
Available from the
Office of Technical Services
Department of Commerce
Washington $25, D . C$.

August 2, 1950

Y-12 Plant

Carbide and Carbon Chemicals Corporation

Oak Ridge, Tennessee

Technical Information Service Extension, Oak Ridge, Tenn. 


\section{DISCLAIMER}

This report was prepared as an account of work sponsored by an agency of the United States Government. Neither the United States Government nor any agency Thereof, nor any of their employees, makes any warranty, express or implied, or assumes any legal liability or responsibility for the accuracy, completeness, or usefulness of any information, apparatus, product, or process disclosed, or represents that its use would not infringe privately owned rights. Reference herein to any specific commercial product, process, or service by trade name, trademark, manufacturer, or otherwise does not necessarily constitute or imply its endorsement, recommendation, or favoring by the United States Government or any agency thereof. The views and opinions of authors expressed herein do not necessarily state or reflect those of the United States Government or any agency thereof. 


\section{DISCLAIMER}

Portions of this document may be illegible in electronic image products. Images are produced from the best available original document. 


\title{
HYDROFLUORINATION OF ZIRCONIUM OXIDE
}

\author{
By Don Phillips
}

\section{INTRODUCTION}

Quantity production of pure, ductile zirconium metal is a very difficult operation. One of the processes which has shown promise in preliminary, small scale tests involves reduction of zirconium tetrafluoride with calcium metal. For these experimental reductions, performed in the Stable Isotope Department, the zirconium tetrafluoride was prepared on a small scale by personnel from that department. Since successful demonstration of the reduction process might lead to immediate demands for $\mathrm{ZrF}_{4}$, an experimental program was initiated to establish the optimum conditions for this hydrofluorination. This program has been terminated short of its objective by press of more urgent work. The experimental effort along with such conclusions as seem justified is discussed in this document.

The thiocyanate process for removal of hafnium from zirconium may be utilized to yield the zirconium in any of three readily available forms. To avoid contamination from this element the zirconium material for hydrofluorination must be carbon-free. This restriction eliminates the organic acid precipitates of zirconium and their partially calcined products and leaves for consideration only the completely calcined $\mathrm{ZrO}_{2}$ as a readily available raw material for hydrofluorination.

Of the variables which need study in a vapor-solid reaction of this type only reaction time and reaction temperature have been investigated. All experiments have used the same apparatus, sample size, and have used $\mathrm{ZrO}_{2}$ ground to pass 100-mesh screens as the efficiency of contacting of solid with vapor was, to a first approximation, the same in all runs. No study of the effect of method of preparation of the oxide on its reactivity has been made. Since the zirconium oxide used was prepared in several relatively small batches, however, it is possible that the oxide used varied considerably in reactivity from run to run. It is suggested that a systematic study of methods and conditions of pretreatment might yield a zirconium oxide of considerably improved reactivity.

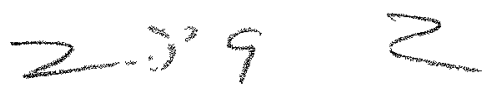


It was realized that contamination of the product by materials of construction used would occur. No attempt has been made in this research to avoid this contamination. This important problem must be faced before satisfactory $\mathrm{ZrF}_{4}$ can be produced in quantity.

\section{EXPERIMENTAL}

Apparatus. The reactor assembly, as shown in Figure 1, was contained in two sections of 1 -inch monel pipe flanged together and fitted with connections to permit inlet and exit of reaction gases. The reaction chamber was a monel thimble fitting closely inside the 1 -inch pipe and held in place just below the flanged connection by three lugs welded into the pipe. The perforated thimble bottom was covered with 60 -mesh stainless steel screen to prevent loss of charge material and to afford even distribution of hydrofluoric acid vapor. A nickel thermowell extended from the top of the reactor into the thimble and terminated near the center of the charge. The reactor was heated by a 1-inch tube furnace placed so that the reacting bed was near the center of the furnace.

The inert gas used was freed from oxygen and nitrogen by passage through heated tubes containing copper turnings and titanium turnings.

Procedure, Preliminary experiments utilized zirconium oxide prepared by calcination at $800^{\circ} \mathrm{C}$ for four hours of crude oxide, containing considerable free carbon, and of zirconium salicylate both obtained from the hafnium-removal plant. The oxide prepared directly from the zirconium salicylate appeared easier to grind and was accordingly adopted for all subsequent tests.

For these tests calcination in the temperature range $780^{\circ}$ to $800^{\circ} \mathrm{C}$ for four hours was used to produce the $\mathrm{ZrO}_{2}$. It was noted that, even over this narrow temperature range, the materials showed difference in ease of grinding and difference in rate of removal of carbon in the furnace.

The charge, consisting of 15 grams of -100 -mesh material, was charged into the reactor and heated, in an inert atmosphere. For this purpose argon was used for experiments $1,2,3,4,7,8,9,10$, and 11 with Grade $\mathrm{A}$ helium used for the remainder. The experimental conditions used are shown in Table 1 below. In every experiment at least a 10 -fold excess of HF was passed over the charge. Hydrogen was used in some experiments as indicated in the table below at the rate of 2 cubic feet per hour. After hydrofluorination for the predetermined interval the product was cooled to room temperature under the inert atmosphere before the reactor was opened.

The completeness of reaction has been ascertained in each case by determination of the zirconium content of representative samples of the product.

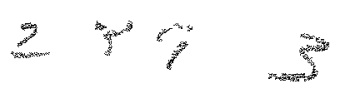




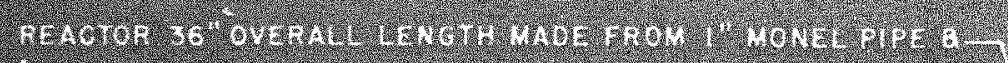

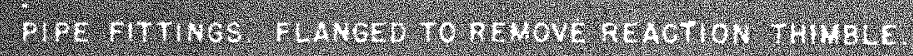

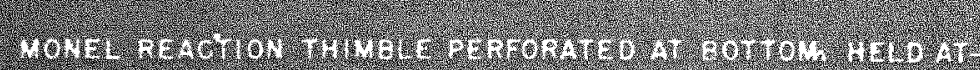

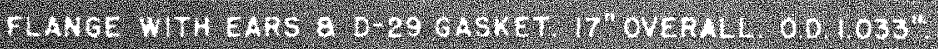

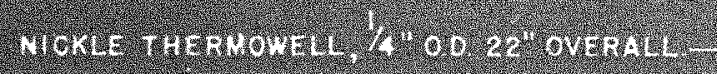

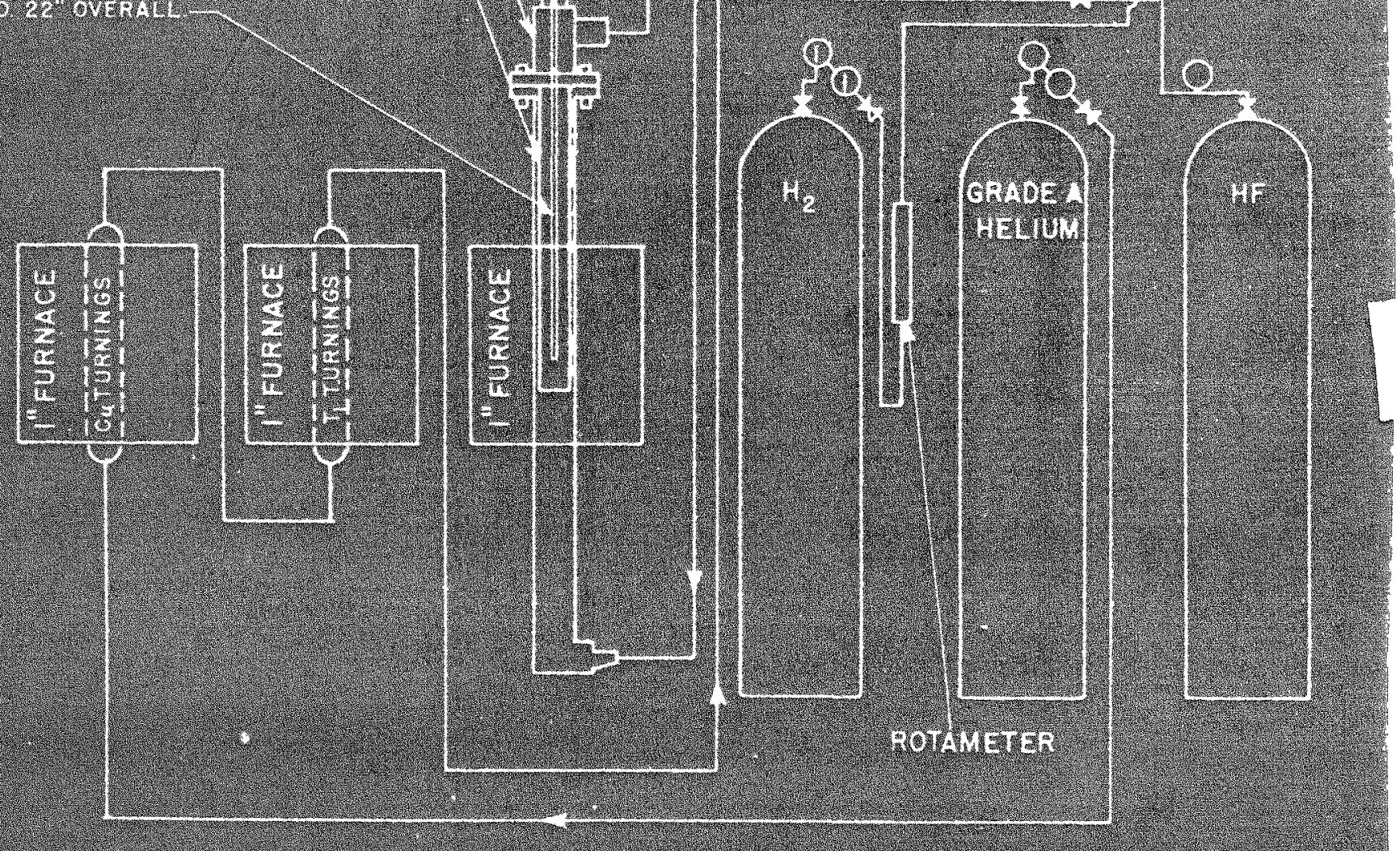


Table 1-Completeness of Hydrofluorination Under Various Reaction Conditions

\begin{tabular}{|c|c|c|c|c|c|c|}
\hline \multirow[b]{2}{*}{$\begin{array}{c}\text { Experiment } \\
\text { Number }\end{array}$} & \multicolumn{2}{|c|}{ Hydrogenation Conditions } & \multicolumn{2}{|c|}{ Hydrofluorination Conditions } & \multirow{2}{*}{$\begin{array}{l}\text { Product } \\
\text { Analysis } \\
(\% \mathrm{Zr})\end{array}$} & \multirow{2}{*}{$\begin{array}{c}\text { Completeness } \\
\text { of Reaction } \\
(\%)\end{array}$} \\
\hline & $\begin{array}{l}\text { Time } \\
\text { (hrs.) }\end{array}$ & $\begin{array}{c}\text { Temperature } \\
\left({ }^{\circ} \mathrm{C}\right)\end{array}$ & $\begin{array}{l}\text { Time } \\
\text { (hrs.) }\end{array}$ & $\begin{array}{c}\text { Temperature } \\
\left({ }^{\circ} \mathrm{C}\right)\end{array}$ & & \\
\hline 1 & None & None & 4 & 400 & 70.0 & 20,5 \\
\hline 2 & None & None & 4 & 500 & 66.7 & 37.4 \\
\hline 3 & None & None & 4 & 600 & 62.6 & 58.5 \\
\hline 4 & None & None & 4 & 700 & 55.4 & 95.4 \\
\hline 5 & None & None & 4 & 750 & 55.9 & 92.8 \\
\hline $6^{*}$ & None & None & 4 & 800 & 54.5 & 100 \\
\hline 7 & 2 & 600 & 4 & 400 & 58.5 & 79.5 \\
\hline 8 & 2 & 600 & 4 & 500 & 66.5 & 38.4 \\
\hline 9 & 2 & 600 & 4 & 550 & 60.3 & 70.2 \\
\hline 10 & 2 & 600 & 4 & 600 & 57.5 & 84.6 \\
\hline 11 & 2 & 600 & 4 & 700 & 54.7 & 100 \\
\hline 12 & None & None & 5 & 600 & 56.1 & 91.8 \\
\hline 13 & None & None & 6 & 600 & 55.3 & 95.9 \\
\hline 14 & None & None & 2 & 700 & 54.6 & 100 \\
\hline 15 & None & None & 3 & 700 & 54.3 & 100 \\
\hline $16 \dagger$ & 4 & 650 & 4 & 650 & 54.7 & 100 \\
\hline $17 \dagger$ & 4 & 650 & 4 & 650 & 55.7 & 93.8 \\
\hline 18 車 & None & None & 4 & 750 & 56.5 & 89.7 \\
\hline
\end{tabular}

* Finished product had been fused. Some evidence of sublimation noted. $\uparrow$ Simultaneous treatment with hydrogen and HF.

Pelletized material used. Pellets almost intact at termination of run with slight evidence of fusion noted. 
CONCLUSIONS

It will be noted that 5 of the 18 reactions yielded completely hydrofluorinated material. Of these five experiments three were performed without added hydrogen and utilized temperatures of 700 to $800^{\circ} \mathrm{C}$. The other two, in which hydrogen was used prior to, or simultaneously with, the $\mathrm{HF}$, were complete at 700 and at $650^{\circ} \mathrm{C}$ respectively.

Completeness of hydrofluorination at constant reaction time is increased by increase in reaction temperature. The evidence from experiments 3,12 , and 13 and from 14 and 15 indicates considerable increase in completion at longer times at constant temperature as is to be expected.

Hydrogenation either prior to or during hydrofluorination appears to be beneficial. Pelletizing of the $\mathrm{ZrO}_{2}$ appears to have a very slight detrimental effect.

There are, however, a number of anomalous results in the table. It is suggested that the reactivity of the oxide may vary considerably with small variations in its manner of preparation and that this important and uncontrolled variable may be responsible for some of the discrepancies observed. It is suggested that study of hydrofluorination as a function of preconditioning of the oxide would be quite valuable if this reaction were to acquire considerable importance.

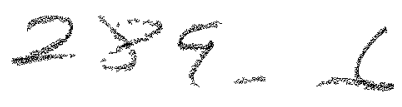

